\title{
„NIE CHCEMY TEGO UKRYWAĆ” - OCZAMI ŚWIADKÓW. SYTUACJA DUSZPASTERSTWA POLONIJNEGO W PÓŁNOCNEJ FRANCJI W 1928 ROKU
}

Powołanie 13 maja 1922 r. „Misji Polskiej Katolickiej we Francji” tworzyło płaszczyznę porozumienia i współdziałania mającego na celu zapewnienie liczącej setki tysięcy osób zbiorowości polskiej w tym kraju, właściwej opieki religijnej. Szczegóły funkcjonowania Misji zostały zawarte w tymczasowym „Reglement" (Statucie), zatwierdzonym przez arcybiskupów Paryża i Gniezna-Poznania 16 czerwca 1922 r., i ostatecznie opracowanym i ogłoszonym przez obydwie strony w 1924 r. ${ }^{1}$ Władze kościelne we Francji na zebraniu 2-3 marca 1924 r. pod przewodnictwem bpa Emmanuela Chaptala, koadiutora archidiecezji paryskiej utworzyły stosowną komisję, której zadaniem była troska o życie religijne emigrantów. Ponadto, 15-16 marca 1927 r. na zebraniu plenarnym Episkopatu Francji zobowiązano biskupów, mających w swych diecezjach większą liczbę emigrantów do skoordynowanych działań mających na celu zapewnienie opieki duszpasterskiej cudzoziemcom ${ }^{2}$. Niemniej, charakteryzując posługę duszpasterską we Francji, jeden z ówczesnych duszpasterzy - ks. Józef Łuczak - napisał: „Warunki pracy duszpasterskiej są dla wszystkich bardzo trudne. Duszpasterstwo polskie we Francji bowiem znajduje się w wyjątkowych warunkach, bo Misja Polska nie ma tam podstaw ogólno-prawnych, lecz racja jej egzystencji opiera się jedynie na dość problematycznej umowie, zawartej między kard. [Edmundem] Dalborem a kard. [Louis] Dubois, arcybiskupem Paryża. Nie jest ona dość obwarowana, by zapobiec tendencjom episkopatu francuskiego nie zawsze przychylnym naro-

* ks. Józef Szymański - dr historii Kościoła, adiunkt w Ośrodku Badań nad Polonią i Duszpasterstwem Polonijnym KUL

${ }^{1}$ M. Brudzisz CSsR, Pierwsze zebranie księży Polskiej Misji Katolickiej we Francji, „Studia Polonijne", 33 (2012) s. 141-144; G. Garçon, Les catholiques polonais en France. Les années de fondation 1919-1949, Lille 2004, s. 15-49; Ks. A. Poszwa, L’Émigration Polonais Agricole en France, Paris 1930.

2 R. Dzwonkowski SAK, Polska opieka religijna we Francji 1909-1939, Poznań-Warszawa 1988, s. 73. 
dowemu duchowi wychodźstwa. Część biskupów wypowiedziała swoje zamiary otwarcie w dekrecie bpa Chaptal'a, sufragana paryskiego, potwierdzonym przez kard. J. Verdiera, arcybiskupa paryskiego. Okólnik ten dotyczy wprawdzie wszystkich obcych narodowości, ze względu na liczebnie największą ilość Polaków we Francji, ma on znaczenie przede wszystkim dla robotników narodowości polskiej. W dekrecie tym znamiennym żąda się, 1) żeby dzieci, rozumiejące już po francusku posyłać na katechizm do księży francuskich i zapisywać do francuskich towarzystw parafialnych, 2) żeby dzieci, które po francusku jeszcze nie rozumieją i które uczono w języku rodziców, dopuszczono do Komunii św. tylko prywatnie. Uroczyste przyjęcie i dalszą ich katechizację ma się pozostawić księżom francuskim, 3) żeby zachęcać osoby starsze już dorosłe do wstępowania w szeregi organizacji parafialnych francuskich i do wypełniania praktyk religijnych w języku francuskim po parafiach francuskich, założone wśród obcokrajowców towarzystwo religijne można tolerować, lecz pod ścisłą kontrolą administracji diecezjalnej francuskiej dla cudzoziemców"3.

O wspomnianych trudnościach dotyczących pełnienia posługi duszpasterskiej wśród rodaków informowali rektora Polskiej Misji Katolickiej (dalej: PMK) - ks. Wilhelma Szymbora duszpasterze polscy. W ankiecie z 3 maja 1928 r. ks. Czesław Garstecki ${ }^{4}$ napisał: „zbyt wielkiej życzliwości ani przychylności dla sprawy naszej, polsko katolickiej nie znajduję, szczególnie gdy chodzi o teren północny. Nie chciałbym tego uogólniać, w większości wypadków jednakże wydaje się jakoby

${ }^{3}$ Cyt. za: Ks. J. Łuczak, Wychodźtwo polskie we Francji, (Odbitka z „Roczników Katolickich” na rok 1932), Łomża 1932, s. 7-8.

${ }^{4}$ Kapłan archidiecezji poznańskiej. Urodził się 14 czerwca 1896 w Poznaniu. Syn Marcina i Stanisławy z d. Maniewska. Uczęszczał do gimnazjum św. Marii Magdaleny. Po uzyskaniu świadectwa dojrzałości, 1 lipca 1923 wstąpił do Wyższego Seminarium Duchownego w Poznaniu. 26 maja 1923 w Gnieźnie, przyjął święcenia kapłańskie z rąk kard. E. Dalbora. Pracował jako wikariusz w parafii św. Mikołaja w Inowrocławiu. Posługę duszpasterską wśród wychodźstwa polskiego we Francji rozpoczął 20 marca 1926 w Lens, jako dyrektor stowarzyszeń i bractw kościelnych we Francji, a od 1 marca 1933 w Sallaumines także jako duszpasterz wśród polskich górników kopalni Bethune, zamieszkujących w Auchy, Mazingarbe, Brebis. Po powrocie do kraju, 15 grudnia 1935 został proboszczem w Baszkowie. 1 stycznia 1937 objął parafię św. Stanisława Kostki w Poznaniu. Podczas okupacji posługę duszpasterską pełnił na terenie Nałęczowa. Po zakończeniu działań wojennych na nowo podjął posługę w tej samej parafii. Zmarł po nabożeństwie na schodach kościoła 20 maja 1953. Pochowany na cmentarzu parafialnym.

Archiwum Polskiej Misji Katolickiej we Francji. J. Misje - ośrodki duszpasterskie. II. Dekanat Pas de Caleais. 8. Lens. 8. 1. Korespondencja 1929-1947; 15. Salaumines 1929-1986. 1. Korespondencja 1929-1939; P. Personalia. I. P. I. „Akta osobowe księży”, do 1939, 14. Garstecki Czesław; P. V. Akta osobisto duszpasterskie księży pracujących w ośrodkach duszpasterskich PMK we Francji, gromadzone po 1945, 65. Garstecki Czesław; Materiały do dziejów Polskiej Misji Katolickiej we Francji. Zeszyt IV II/II. Księża polscy w duszpasterstwie Pótnocnej Francji 1922-1929, O. B. Panek OC, Paris 1992, s. 83-86; Materiały do dziejów Polskiej Misji Katolickiej we Francji. Zeszyt XVIII. Duchowieństwo polskie we Francji od 1922 r. Prezentacja stanu badań - katalog, O. B. Panek OC, Paris 1996, s. 34; „Miesięcznik Kościelny Archidiecezji Poznańskiej”, 8 (1957), s. 291-292; M. Banaszak, Garstecki Czesław (1896-1953), w: Stownik Polskich Teologów Katolickich 1918-1981, red. Ks. L. Grzebień SJ, Warszawa 1983, s. 426-427. 
tutejsi księża kapłana polskiego mieli za coś niższego, nie zaś za konfratra. Objawia się to tym, że albo brak dobrego czyli godziwego konfesjonału, bo właściwy stoi jedynie do dyspozycji miejscowego proboszcza, choć nie ma penitentów, co prawda zachodzi to już rzadziej, częściej w tym, że chociaż w czasie mszy św. dla Polaków proboszcz tylko wejdzie do kościoła, by zebrać składkę i wyjść, nie zezwala na zapalenie pewnej ilości świec na ołtarzu, nawet liturgicznie przepisanych, nie mówiąc już o tym, że składka starczyłaby na to, żeby z okazji uroczystej mszy św. ołtarz odpowiednio oświecić. [...] proboszcz mimo, że ksiądz polski jest w kościele, nie pozwoli udzielić ślubu lub chrztu św. przybyłym do kościoła Polakom, chociaż widzi, że przybyli Polacy go nie rozumieją, a ksiądz polski chętnie by to uczynił"s.

Podobną opinię we wspomnianej ankiecie wyraził ks. Antoni Ościłowicz „Stosunki moje z proboszczami francuskimi są dobre, z niektórymi jak najlepsze. Inaczej sprawy się mają z miejscowym księdzem proboszczem w Hayange - archiprezbiterem - od pierwszej naszej znajomości coś żywi do mnie, do czego o ile mi się zdaje nie dałem żadnych powodów ani czynnych ani też biernych. Razu pewnego, jest temu rok, przy naszym widzeniu się, zrobili mi zarzut, że nie mam sali, gdzie by można dla robotników konferencję i pogadanki urządzić, i że nie powinienem dużo nabierać polskich kolonii, lepiej bowiem - tłumaczył, mieć ich mniej a dobrze się w nich urządzić. Dałem mu w tej sprawie wyjaśnienie i prosiłem o pomoc. Czy w samej rzeczy chodzi tu o chwałę Bożą i dobro naszych rodaków? Co i jak sądzi o mnie tutejsza władza diecezjalna nie wiem - jestem tej, jak prawo każe - uległym synem"’.

Sprawę tę podnosili podczas obrad uczestnicy Zjazdu Katolickiego w Lens ${ }^{8}$. Bezpośrednią jednak odpowiedzialność za nią brali na siebie duszpasterze polscy pełniący posługę duszpasterską wśród rodaków. Ich działania „zmierzające” do powstrzymania procesu wynaradawiania swoich rodaków, są owym „niemym krzykiem", który egzemplifikuje m.in. poniższy dokument.

${ }^{5}$ Cyt. za: Materiaty do dziejów Polskiej Misji Katolickiej we Francji. Zeszyt IV II/II. Księża polscy w duszpasterstwie Pólnocnej Francji 1922-1929, O. B. Panek OC, Paris 1992, s. 84-85; Zob. Cz. Garstecki, Rola duchowieństwa polskiego w życiu emigracji polskiej we Francji, „Teologia Praktyczna”, 1 (1939-reprint 2001), s. 248.

${ }^{6}$ Kapłan archidiecezji wileńskiej. Urodził się 24 stycznia 1868. Święcenia kapłańskie przyjął w marcu 1895. Pracował w parafiach: 1901-1906 - Turośń, dekanat białostocki (wikariusz); 19061915 - Krewo, d. Oszmiana (administrator). W czasie I wojny światowej był przez 3 lata kapelanem w obozach jenieckich (15) wśród jeńców wojennych armii rosyjskiej w Bawarii. W 1920 był administratorem w Szarkowszczyźnie. W 1925 był proboszczem i dziekanem w Miorach. Obowiązki duszpasterskie we Francji podjął 13 października 1926 w Hayange (Moselle). Od 7 listopada 1928 do 1 listopada 1933 pracował w koloni polskiej w Harnes. W 1. 1935-1936 był proboszczem parafii Idołta, a w 1938 proboszczem w Żydomi, d. Grodno. Zmarł w 1954.

Archiwum Polskiej Misji Katolickiej we Francji. P. Personalia. I. 54, Ościłowicz Antoni; J. Misje - ośrodki duszpasterskie. II. Dekanat Pas de Caleis. 7. Harnes 1929-1988; Materiały do dziejów Polskiej Misji Katolickiej we Francji. Zeszyt III. Księża polscy w duszpasterstwie Dekanatu Wschodniego 1922-1929, O. B. Panek OC, Paris 1992, s. 83-86.

${ }^{7}$ Materiaty do dziejów Polskiej Misji Katolickiej we Francji. Zeszyt III, s. 83-86.

${ }^{8}$ Luczak, Wychodźtwo polskie we Francji, s. 23-24. 
Dokument oryginalny w formie rękopisu, przechowywany jest w Archiwum Archidiecezjalnym w Gnieźnie, Archiwum Prymasa Polski, Akta Protektora Wychodźstwa Polskiego, Francja, Dział III/16, X. J. Radwański, Dziekan Północnej Francji, Do Jego Eminencji Księdza Kardynała Augusta Hlonda Prymasa Polski w Poznaniu, Bruay en Artois (P.de.C.) 15 - X - 1928 r. k. 8.

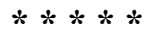

Do

Jego Eminencji

Księdza Kardynała Augusta Hlonda

Prymasa Polski w Poznaniu

Wasza Eminencjo!

Dnia 3 października [1928] odbyło się w Lens dekanalne zebranie księży polskich z dekanatu Północnej Francji.

Przybyli księża następujący: ks. [Józef Jan] Radwański ${ }^{9}$,

${ }^{9}$ Kapłan diecezji płockiej; od 11 listopada 1925 kapłan diecezji łomżyńskiej. Urodził się 10 marca 1891 w Warszawie. Syn Leona i Marii z d. Syska. Szkołę średnią ukończył w Siedlcach. Po ukończeniu w 1916, Wyższego Seminarium Duchownego w Płocku, 17 czerwca 1916 przyjąl święcenia kapłańskie. Pełnił obowiązki wikariusza w Mławie, od czerwca 1918 w Płońsku, od grudnia 1918 w Kadzidle i od 1920 w Rzekuniu. Od 15 stycznia 1926 pracował wśród Polaków we Francji, początkowo w Nancy, później, od 1 października 1928 w Bruey en Artois (gdzie wybudował kościół w 1930). Od marca 1928 był dziekanem w północnej części Francji. Od 1 lipca 1931 przebywał na trzymiesięcznym urlopie w USA.

Po 8 latach pracy w duszpasterstwie polonijnym, 31 marca 1931 został zwolniony z obowiązków duszpasterskich we Francji i powrócił do kraju. 13 kwietnia 1934 został proboszczem w Rajgrodzie. Przy nowym kościele w 1936 wybudował plebanię. Był jednym z pomysłodawców i organizatorów budowy szkoły. W czasie II wojny światowej był żołnierzem ZWZ, następnie AK. Na terenie białostockiego okręgu AK - obwód augustowski, pełnił funkcję kierownika propagandy. Posiadał stopień podporucznika i pseudonim „Bywały”. 25 września 1940 został aresztowany przez NKWD. 27 maja 1941 został skazany przez Trybunał Wojenny w Mińsku na karę śmierci przez rozstrzelanie i konfiskatę mienia. W oficjalnych dokumentach brakuje potwierdzenia o wykonaniu wyroku [24 czerwca 1941], nigdy jednak nie powrócił do swej parafii. Pośmiertnie został odznaczony Krzyżem Walecznych przez dowództwo AK.

Ks. W. Jemielity, Martyrologium księży diecezji lomżyńskiej 1939-1945, „Rozporządzenia Urzędowe Łomżyńskiej Kurii Diecezjalnej”, 36 (1974) nr 8-9, s. 55; Materiały do dziejów Polskiej Misji Katolickiej we Francji. Zeszyt III. Księża polscy w duszpasterstwie Dekanatu Wschodniego 1922-1929, O. B. Panek OC, Paris 1992, s. 89-90; Materiały do dziejów Polskiej Misji Katolickiej we Francji. Zeszyt XVIII, s. 79; Archiwum Polskiej Misji Katolickiej we Francji. J. Misje - ośrodki duszpasterskie. II. Dekanat Pas de Caleis. 4. Bruay en Artois. 4. 1. Dokumentacja 1929-1945. 
ks. [Władysław] Wyderka ${ }^{10}$,

ks. [Antoni] Tworek ${ }^{11}$,

ks. [Edmund] Wołkowski ${ }^{12}$,

${ }^{10}$ Kapłan (archi)diecezji przemyskiej. Urodził się 4 lipca 1891 w Szebniach k. Jasła. Syn Jana i Zofii z. d. Woźniak. W 1. 1905-1913 uczęszczał do gimnazjum w Jaśle i Przeworsku. Seminarium Duchowne w Przemyślu ukończył w 1918. Święcenia kapłańskie przyjął 12 maja 1918. Był wikariuszem w Haczowie i Przeworsku (1918-1926). Od kwietnia 1926 r. pracował jako duszpasterz polonijny w Bruay en Artois, we Francji. Pomimo uzyskanej 20 maja 1935 zgody bpa F. Bardy na objęcie funkcji rektora Polskiej Misji Katolickiej w Belgii nie podjął się tego zadania. Po powrocie do diecezji, od 1 lutego 1938 został kanclerzem kurii. Urząd ten sprawował do 1976. W 1949 otrzymał kanonię w przemyskiej kapitule katedralnej, a w 1967 - scholasterię. W 1974 został mianowany protonotariuszem apostolskim. Zmarł 21 lutego 1987 w Przemyślu.

Archiwum Archidiecezjalne w Przemyślu, Akta personalne księży. Teczka personalna, Tabela służbowa ks. W. Wyderki, b. sygn., b.s.; Archiwum Polskiej Misji Katolickiej we Francji. J. Misje - ośrodki duszpasterskie. II. Dekanat Pas de Calais. 4. Bruay en Artois. 4. 1. Dokumentacja 19291945; Ks. J. Szymański, Duszpasterze Polonii i Polaków w świecie, Stownik biograficzny, T. 1, Lublin 2010, s. 164; Materiały do dziejów Polskiej Misji Katolickiej we Francji. Zeszyt XVIII, s. 97.

${ }^{11}$ Kapłan diecezji sandomierskiej. Urodził się 5 stycznia 1897 w Łoniowie k. Sandomierza. Syn Wojciecha i Jadwigi z d. Hołodna. Początkowo uczył się w miejscowej szkole powszechnej, następnie w gimnazjum męskim w Sandomierzu. Studia filozoficzno-teologiczne ukończył w Seminarium Duchownym w Sandomierzu. Święcenia kapłańskie przyjął w 1920. Posługę duszpasterską rozpoczął jako wikariusz parafii Ćmielów, gdzie pracował do października 1922. W tymże roku rozpoczął studia w Katolickim Uniwersytecie Lubelskim, które ukończył w 1926 obroną pracy doktorskiej na wydziale prawa kanonicznego.

Po ukończeniu studiów został skierowany do pracy duszpasterskiej w duszpasterstwie emigracyjnym we Francji. Pracował w Montceau les Mines, a następnie w Barlin. Był kandydatem na rektora Polskiej Misji Katolickiej w Belgii. W 1929 zrzekł się wspomnianej placówki na skutek trudnych warunków pracy i złego stanu zdrowia. Po krótkim urlopie zdrowotnym pracował nadal we Francji (Oignies). W listopadzie 1930, z powodu ogólnego osłabienia, powrócił do kraju. Został notariuszem Sądu Biskupiego i rektorem podominikańskiego kościoła św. Jakuba w Sandomierzu. Od czerwca 1932 był spowiednikiem zwyczajnym alumnów, a ponadto od kwietnia 1937 do października 1939 pełnił obowiązki kuratora Domu Księży Emerytów. W 1934 został sekretarzem redakcji czasopisma diecezjalnego „Prawda Katolicka”; patronem Stowarzyszenia Robotników Chrześcijańskich; od 1934 do 1936 był asystentem kościelnym Katolickiego Stowarzyszenia Mężów oraz Katolickiego Stowarzyszenia Kobiet; w 1936 wybrany został na członka zarządu Stowarzyszenia Kupców Chrześcijańskich. W 1937 doprowadził do powstania Chrześcijańskiej Kasy Bezprocentowej, w której pełnił obowiązki wiceprezesa. 12 marca 1940 został wiceoficjałem Sądu Biskupiego, a 14 marca tegoż roku został odznaczony godnością kanonika honorowego Kapituły Katedralnej Sandomierskiej.

16 marca 1942 w Sandomierzu został aresztowany przez Gestapo. Jeszcze w tym samym miesiącu został wywieziony do obozu koncentracyjnego w Oświęcimiu, a 5 czerwca 1942 do Dachau (nr obozowy 30275). Tam zmarł w wigilię Bożego Narodzenia 1942.

Materiaty do dziejów Polskiej Misji Katolickiej we Francji. Zeszyt XVIII, s. 94; E. Weiler, Die Geistlichen in Dachau sowie in anderen Konzentrationslagern und in Gefängnissen, Mödling 1971, s. 676.

${ }^{12}$ Kapłan archidiecezji poznańskiej. Urodził się 13 października 1897 w Inowrocławiu. Syn Stanisława i Marianny z d. Kaus. Po uzyskaniu w tamtejszym gimnazjum świadectwa dojrzałości 15 


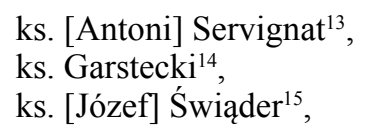

marca 1918, wstąpił do Wyższego Seminarium Duchownego w Poznaniu. Święcenia kapłańskie przyjął 17 grudnia 1922. Od stycznia 1923 był wikariuszem w parafii MB Bolesnej w Poznaniu. Posługę duszpasterską wśród wychodźstwa polskiego we Francji rozpoczął 1 stycznia 1927 w Dechy, skąd 1 czerwca tegoż roku został przeniesiony do Lens. 17 października 1929 po powrocie do kraju został dyrektorem Poznańskiego Okręgu Caritas i redaktorem miesięcznika Związku Towarzystw Dobroczynności Caritas. 30 czerwca 1937 został dyrektorem Fundacji Twardowskich w Poznaniu. Od 10 września 1940 zaangażował w posługę społeczną i duszpasterską w Lizbonie. 10 lipca 1941 opuścił Portugalię z wizą kanadyjską.

Archiwum Polskiej Misji Katolickiej we Francji. J. Misje - ośrodki duszpasterskie. II. Dekanat Pas de Caleis. 8. Lens. 8. 1. Korespondencja 1929-1947; Materiaty do dziejów Polskiej Misji Katolickiej we Francji. Zeszyt IV II/II, s. 137-138; Materiały do dziejów Polskiej Misji Katolickiej we Francji. Zeszyt XVIII, s. 96; S. Schimitzek, Na krawędzi Europy. Wspomnienia portugalskie 19391946, Warszawa 1970, s. 277, 285, 296, 353.

${ }^{13}$ Kapłan diecezji kamienieckiej. Urodził się 17 kwietnia 1873 w Żytomierzu. Święcenia kapłańskie przyjął 25 czerwca 1899. Posługę duszpasterską wśród wychodźstwa polskiego we Francji rozpoczął 22 marca 1923 w Lallaing (Nord), skąd 1 sierpnia 1925 został przeniesiony do Calanne Lievin. 1 sierpnia 1934 z uwagi na podeszły wiek został zwolniony z posługi duszpasterskiej. W 1941 był kapelanem szpitala w Gostyniu Wielkopolskim. Tamże, 6 października 1941 został aresztowany przez Gestapo. Od 30 października 1941 przebywał w Dachau (nr obozowy 28085). Wywieziony na śmierć w transporcie inwalidów 28 maja 1942.

Archiwum Polskiej Misji Katolickiej we Francji. J. Misje - ośrodki duszpasterskie. II. Dekanat Pas de Calais. 9. Lievin 1929-1982; Materiały do dziejów Polskiej Misji Katolickiej we Francji. Zeszyt IV II/II, s. 122-124; Materiały do dziejów Polskiej Misji Katolickiej we Francji. Zeszyt XVIII, s. 83; Weiler, Die Geistlichen in Dachau, s. 599; W. Rosowski, Dzieje rzymskokatolickiej diecezji kamienieckiej w latach 1918-1941, Lublin 2008, s. 155, 160.

${ }^{14}$ Zobacz przypis 4.

${ }^{15}$ Kapłan archidiecezji krakowskiej. Urodził się 18 listopada 1886 w Lubaszu k. Szczucina. Syn Antoniego. Ukończył szkołę ludową w Szczucinie. Naukę kontynuował w gimnazjum w Tarnowie i Podgórzu. Od 1908, przez dwa lata studiował na Politechnice Lwowskiej. Przez rok był ochotnikiem 16 pułku obrony krajowej. Od 16 września 1910 studiował filozofię i teologię na Wydziale Teologicznym Uniwersytetu Jagiellońskiego. Święcenia kapłańskie z rąk kard. A. Sapiehy przyjął 29 czerwca 1914. Od 1 sierpnia 1914 był wikariuszem w Oświęcimiu; 15 grudnia 1915 został wikariuszem w Wiśniowej. 1 sierpnia 1919 został katechetą w Makowie Podhalańskim. 15 grudnia 1920 został wikariuszem w Wadowicach. W 1923 został wikariuszem w parafii św. Mikołaja w Krakowie, a w 1925 był wikariuszem w parafii św. Stefana Męczennika w Krakowie, w ostatnim roku [1928] administrował tą parafią. 1 sierpnia 1928 podjął obowiązki duszpasterskie wśród wychodźstwa polskiego we Francji. Od 1 września 1928 pełnił je w Billy Montigny (Pas de Calais); od 1 sierpnia 1932 w Royale par Ales i od 1 lipca 1933 w L' Abbaye les Cendras do 1 lipca 1935. Po powrocie do kraju, 15 października 1935 objął parafię w Zawoi. 1 września 1947 przybył do Kęt, gdzie zmarł 16 maja 1972.

A. Kapuśniak, Ks. J. Szczepaniak, Katalog alumnów krakowskiego seminarium duchownego (1901-1938), Kraków 2006, s. 243; Materiały do dziejów Polskiej Misji Katolickiej we Francji. Zeszyt IV II/II. Księża polscy w duszpasterstwie Pólnocnej Francji 1922-1929, O. B. Panek OC, Paris 1992, s. 89-90; Materiały do dziejów Polskiej Misji Katolickiej we Francji. Zeszyt XVIII, s. 90. 


\section{ks. [Szczepan] Misiak ${ }^{16}$, \\ ks. [Jan] Sadowski ${ }^{17}$, \\ ks. Ościłowicz ${ }^{18}$, \\ ks. [Franciszek] Hyla ${ }^{19}$.}

${ }^{16}$ Kapłan archidiecezji gnieźnieńskiej. Urodził się 25 grudnia 1894 w Grodzisku nad Prosną. Do szkoły powszechnej uczęszczał w rodzinnej miejscowości. Od 1910 naukę pobierał w Collegium Marianum Księży Pallotynów w Wadowicach, a od 1914 w gimnazjum w Niemczech. W 1916 został powołany do służby wojskowej, do 1918 przebywał na froncie francuskim. Początkowo, przez trzy lata studiował teologię na uniwersytecie w Monasterze, a następnie w Arcybiskupim Seminarium Duchownym w Gnieźnie. Święcenia kapłańskie przyjął 17 grudnia 1922 z rąk kard. E. Dalbora. Przez pół roku pełnił obowiązki duszpasterskie przy kościele farnym w Bydgoszczy. Latem 1923 podją je wśród rodaków we Francji. Początkowo, od 1 lipca 1923 do 1926 w Merlebach (Moselle), następnie dojeżdżał do Freyming (Moselle), później, od 1 lipca do 27 września 1926 do Rosieres (Cher). W Waziers (Nord) pracował od 1 marca 1928 do 1 października 1931, następnie został przeniesiony do Knutange (Moselle), gdzie pełnił obowiązki duszpasterskie do lipca 1932. Stamtąd został przeniesiony do Nilvange (Moselle) do 15 października 1936. Po powrocie do kraju, pracował jako kapelan w więzieniu i dyrektor Caritasu w Inowrocławiu. 2 listopada 1939 został aresztowany i uwięziony w Inowrocławiu, od 5 listopada w Świeciu, od 8 listopada w Górnej Grupie, od 5 lutego 1940 w Gdańsku, od 8 lutego w Stutthofie, od 10 kwietnia w Sachsenchausen, od 14 grudnia 1940 w Dachau (nr obozowy 22 609). Z obozu został zwolniony 16 marca 1943. Po zakończeniu działań wojennych administrował parafią Św. Jakuba i parafią Św. Jana Ap. w Mogilnie, gdzie od 1948 był proboszczem. W 1960 został przeniesiony do Nakła nad Notecią. Tam zmarł 1 grudnia 1963.

Materiały do dziejów Polskiej Misji Katolickiej we Francji. Zeszyt III, s. 79; Materiały do dziejów Polskiej Misji Katolickiej we Francji. Zeszyt XVIII, s. 66; „Wiadomości Archidiecezji Gnieźnieńskiej” 19(1964) nr 3-4, s. 69-70.

${ }^{17}$ Kapłan diecezji płockiej; od 2 stycznia 1922 diecezji Cambrai. Urodził się 24 czerwca 1889 w Cywinach na Ukrainie. We Francji przebywał od września 1908. Gimnazjum ukończył w Poitiers, a studia teologiczne w Paryżu. Święcenia kapłańskie przyjął 29 lipca 1921. Inkardynowany do diec. Cambrai. Od 2 stycznia 1922 pełnił posługę duszpasterską wśród rodaków w: Valenciennes (Nord), od 30 grudnia 1940 w Bourg d'Oisans (Isere), skąd 30 grudnia 1944 powrócił do Valenciennes. Dojeżdżał do (16) polskich kolonii. W rejonie Valenciennes zamieszkiwało 28.000 Polaków. Systematycznie uczestniczył w zebraniach PMK. Zmarł 29 grudnia $1950 \mathrm{w}$ Valenciennes.

Archiwum Polskiej Misji Katolickiej we Francji. P. Personalia. VI. Ankieta personalna kapłanów MPK we Francji 1945(-1950); Panek, Materiały do dziejów Polskiej Misji Katolickiej we Francji. Zeszyt I, s. 101; Materiaty do dziejów Polskiej Misji Katolickiej we Francji. Zeszyt IV II/II, s. 118-119; Materiały do dziejów Polskiej Misji Katolickiej we Francji. Zeszyt XVIII, s. 82.

${ }^{18}$ Zobacz przypis 6 .

${ }^{19}$ (Hylla) - kapłan archidiecezji katowickiej. Urodził się 27 listopada 1889 w Miasteczku Śląskim. Syn Józefa i Marianny z d. Bromisz. W 1910 wstąpił do Zgromadzenia Misjonarzy św. Rodziny w Grave w Holandii. W Zakładzie Zgromadzenia uzyskał wykształcenie średnie. W czerwcu 1915 wyjechał na front. Po zakończeniu wojny w 1918, kolejne 2 lata spędził w angielskiej niewoli w Turcji. Po zwolnieniu w 1920 przystąpił do matury, a następnie rozpoczął roczny nowicjat w Zgromadzeniu Misjonarzy św. Rodziny. Po jego ukończeniu zaczął dwuletnie studia filozoficzne. Od 1923 studiował teologię w domu macierzystym w Grave, a następnie w Kazimierzu Biskupim. W 1924 odszedł ze Zgromadzenia. Do kapłaństwa przygotowywał się dalej w Śląskim Seminarium Duchownym w Krakowie. Święcenia kapłańskie przyjął 20 marca 1926. Początkowo, obowiązki duszpasterskie pełnił w ramach zastępstw, podczas wakacji letnich w Lublińcu. Od 27 lipca 1926 
Ponieważ zebranie to wypadło w tym czasie, kiedy ksiądz rektor został odwołany, przeto sprawozdanie $\mathrm{z}$ jego przebiegu i nasze prośby ośmielamy się przesłać do Waszej Eminencji, który jako Prymas Polski bezpośrednio interesuje i zajmuje się sprawami emigracji.

Porządek dzienny był następujący:

I. Stan moralno - religijny ludności polskiej we Francji.

II. Trudności w pasterzowaniu.

III. Środki zaradcze.

I. Stan moralno - religijny ludności polskiej we Francji przedstawia się niewesoło. Wszystkich można podzielić na 4 grupy.

1) Pokolenie najstarsze

2) Młodzież dorosła

3) Dziatwa

4) Emigracja obecnie przybywająca do Francji.

1) Pokolenie najstarsze, które przebyło już jedną emigrację z Westfalii, mając głęboko zaszczepione zasady wiary św. na ogół zachowuje wiarę św., ale słabo. Kobiety bardziej są religijne, chodzą do kościoła, przystępują częściej do sakramentów św., jednak nie wszystkie. Mężczyźni jednak bardziej są obojętni, mały więc procent przystępuje do komunii św. wielkanocnej. Istnieją co prawda Towarzystwa katolickie, jednak nie wszyscy do nich należą, a i ci, co do nich należą, nie wszyscy są katolikami praktykującymi.

2) Gorzej jest z młodzieżą, która swoje wychowanie otrzymała w szkołach niemieckich w Westfalii.

a) Młodzież męska złączona w Towarzystwa świeckie tzn. kluby kawalerów, towarzystwa sokołów, śpiewacze, teatralne, strzelców itd. prawie zupełnie jest obojętna, znikomy jej procent chodzi do kościoła, jeszcze bardziej znikomy przystępuje do Sakramentów św.

b) Trochę lepiej jest z Młodzieżą Żeńską, ale i tu ten sam objaw spotykamy.

3) Dziatwę, która się wychowała we Francji, można podzielić na 2 grupy. Tam, gdzie był od dłuższego czasu ksiądz polski, ta dziatwa jest lepszą, chodzi do kościoła, częściej przystępuje do sakramentów św., garnie się do Towarzystw, dla niej urządzonych. Tam,

został tam wikariuszem. Pod koniec grudnia 1927 wyjechał do Francji, jako duszpasterz polskich emigrantów. Przebywał tam przez 32 miesiące, pracując w ośrodkach w: Auby (Nord) - od 5 grudnia 1927, Montigny en Ostrevent - od 1 sierpnia 1928, Audun de Tiche.

Po powrocie do Polski, 22 października 1930 został wikariuszem w Rydułtowach. Od 15 lutego 1934 został administratorem parafii Wniebowzięcia NMP w Olszynie, a od 17 maja 1936 jej proboszczem. W 1937 rozpoczął budowę kościoła filialnego w Herbach Śląskich. Na kilka dni przed wybuchem II wojny światowej - 28 sierpień 1939 - został zastępcą wikariusza generalnego na okręg lubliniecki. Czas okupacji spędził w Krzyżkowicach. Po zakończeniu wojny powrócił do Olszyny. Został wicedziekanem, a 6 grudnia 1951 dziekanem dekanatu lublinieckiego (do marca 1961).

Zmarł 4 grudnia 1963 w Olszynie. Został pochowany na miejscowym cmentarzu.

Archiwum Polskiej Misji Katolickiej we Francji. J. Misje - ośrodki duszpasterskie. III. Dekanat Nord. 6. Montigny en Ostrevent. 6.1. Montigny 1929-1939; 1945-1952; Stownik biograficzny duchowieństwa (archi)diecezji katowickiej 1922-2008, red. ks. J. Myszor, Katowice 2009, s. 124-125; J. Gawor, Nekrolog, „Wiadomości Archidiecezjalne” (Katowickie), 62 (1964) z. 3-4, s. 52; H. Olszar, Polska opieka religijna we Francji w okresie międzywojennym i udziat w niej księży diecezji katowickiej, „Wiadomości Archidiecezjalne” (Katowickie), 61(1993), z. 3, s. 139-143; Materiały do dziejów Polskiej Misji Katolickiej we Francji. Zeszyt XVIII, s. 40. 
gdzie ją wychowywał ksiądz francuski, dziatwa naśladuje młodzież francuską, która po przystąpieniu do Uroczystej Komunii Św., zaniedbuje swoje obowiązki religijne.

4) Ci, którzy obecnie przybyli z Polski, ponieważ najczęściej są to ludzie wolnego stanu, kawalerzy albo panny, albo tacy, którzy żony zostawili w Polsce, nie mogąc się przyzwyczaić do naszych warunków i otoczenia, często tracą wiarę i moralność.

Z powyższego przedstawienia wynika, że jest bardzo źle. Tu trzeba jednak zaznaczyć, że w tych koloniach, gdzie ksiądz polski od dłuższego czasu stale pracuje, jest o wiele lepiej, niż w tych, gdzie polskiego księdza nie ma, albo tylko czasami dojeżdża. Gorliwość księdza polskiego i znajomość języka i ducha ludu polskiego czyni to, że wszystkie dzieci chodzą na katechizm, po przystąpieniu do Uroczystej Komunii Św., zapisują się do swoich Towarzystw, a młodzież starsza garnie się do Kościoła, zakłada swoje Towarzystwa katolickie: takie kolonie służą za wzór katolikom francuskim, gdyż ci, widząc gorliwość katolików Polaków, sami chętniej garną się do kościoła i Sakramentów Św.

Gorzej jest w tych koloniach, gdzie ksiądz polski czasami tylko dojeżdża, a najgorzej, gdzie jest tylko ksiądz francuski, który wyuczy się kilku zdań po polsku, udaje już znajomość języka i księdzu polskiemu przyjechać zabrania.

II. Trudności w pasterzowaniu.

Księża wskazywali na różne przyczyny. Jedne były natury powszechnej. A więc ogólny upadek wiary i moralności, zepsucie i bezbożność narodu francuskiego, chęć używania, szkoła świecka itd. Inne przyczyny były natury specjalnej, a mianowicie nieżyczliwy, a często wrogi stosunek księdza francuskiego do księdza polskiego i nieudolny jego sposób pasterzowania w stosunku do ludności polskiej.

I. Ksiądz francuski jest nieżyczliwie, a często wrogo usposobiony do księdza polskiego. Co prawda nie można tego powiedzieć o wszystkich księżach francuskich, są i pomiędzy nimi nieraz dusze prawdziwie apostolskie, gorliwe, ale większości jest nieżyczliwa dla księdza polskiego. Księża francuscy pracę duszpasterską księdza polskiego chcieliby tylko ograniczyć do kazań i do słuchania spowiedzi św. osób dorosłych, chcieliby usunąć wszelki wpływ księdza polskiego, zwłaszcza od dziatwy. Toteż nawet tam, gdzie jest ksiądz polski na stałe w różny sposób odciąga się ludzi od księdza polskiego.

1) Księża francuscy sami chcą chrzcić, błogosławić śluby, grzebać umarłych, dzieci uczyć katechizmu. Nieraz ludzie proszą o księdza polskiego, ten ksiądz często jest obok, ludzie proszą aby ksiądz polski ochrzcił, ślub pobłogosławił, umarłego pochował, ksiądz jednak francuski odmawia, a wtedy ludzie się gorszą, nawet przeklinają i obojętnieją dla wiary św.

2) Księża francuscy polskie dzieci przyciągają na katechizm francuski i na nabożeństwa polskie w ten sposób, że rodzicom, którzy posyłają dzieci na polskie nabożeństwa i polski katechizm, grożą obniżeniem zarobków, wyrzuceniem z pracy, a dzieciom dają cukierki. Ten sposób pasterzowania daje te rezultaty, że dzieci chodzą do kościoła dotąd, dopóki nie przyjmą Uroczystej Komunii Św., a później praktyki religijne zaniedbują. Zresztą naśladują w tym tylko swoich kolegów francuskich.

3) Księża francuscy czasami chowają nawet takich, którym ksiądz polski odmówił chrześcijańskiego pogrzebu; albo odmawiają komunii św. tym, którzy byli u spowiedzi $\mathrm{u}$ księdza polskiego.

4) Gdy ksiądz polski przyjedzie spowiadać, daje mu się często najgorsze miejsca i niedogodne godziny.

5) Na polskim nabożeństwie zapala się dwie świece, (czasami i te zgasną), chociaż ludzi jest pełen kościół, gdy tymczasem na nabożeństwie francuskim zapala się wszystko 
światło, chociaż ludzi jest tylko gromadka. Gdy weźmiemy pod uwagę przywiązanie ludu polskiego do okazałości w nabożeństwach, nikt się nie zdziwi, że lud polski tym się gorszy i od kościoła odchodzi.

Słowem na każdym kroku spotyka się tę nieżyczliwość, to niezrozumienie ludu polskiego, to traktowanie Polaków, jako katolików pośledniego gatunku.

B. Nieudolny sposób pasterzowania księdza francuskiego.

Ksiądz francuski chcąc się przypodobać Polakom, a nie znając ich języka, czynności święte czyni w tak komiczny sposób i tak śmiesznie wymawia polskie wyrazy, że wśród ludu polskiego wzbudza śmiech, politowanie i zgorszenie.

a) Bywały takie wypadki, że przy ślubie ksiądz francuski kazał młodemu wymawiać słowa panny młodej, a pannie młodej na odwrót: toteż młodzi mając skrupuły, przyszli później do księdza polskiego z zapytaniem, czy taki ślub jest ważny. Najczęściej młodzi przed takim ślubem spowiadają się przed księdzem francuskim. Można sobie wyobrazić jak taka spowiedź wygląda i ile daje okazji do spowiedzi świętokradzkiej. To też niejeden Polak umyślnie bierze ślub u księdza francuskiego z tą myślą, aby mógł później żyć na sposób francuski tzn. rozwieść się ze swoją żoną.

b) Bywały wypadki, że ksiądz francuski odmawiał ślubu, chociaż wszystkie papiery były w porządku, dlatego, że na przykład panna młoda była greko-katoliczką, a on nie wiedział co to za wiara.

c) Księża francuscy często zapowiadają tzw. polskie nabożeństwa, na których Polacy odśpiewają z jedną pieśń po polsku, a jeden z obecnych świeckich odczyta ewangelię św. a czasami nawet jakąś naukę. Ten sposób pasterzowania ma tę złą stronę, że ludziom daje zachętę do zakładania sekt „Badaczy” i Kościoła narodowego.

d) Księża francuscy często pisząc metryki popełniają olbrzymie błędy, naprz. jeden z księży widział metrykę urodzenia, gdzie ojciec nazywał się Oberhausen a matka Bottrop, lub gdzie zamiast Roszak, napisze się Rochac, zamiast Makuła - Macquisiela. Przecież ten człowiek nigdy nie znajdzie swej metryki tak zniekształconej.

e) Pewien ksiądz francuski, nieźle mówiący po polsku, zamknął raz pewnego Polaka w zakrystii, aby go obić. Skończyło się na tym, że Polak silniejszy, pobił księdza. Tenże sam ksiądz publicznie księży polskich nazywa „cochons”.

Takich przykładów każdy z księży polskich może przytoczyć dziesiątki. Mają one ten skutek, że księży polskich zniechęcają, zrażają do pracy, do gorliwości, a lud polski gorszą i odstręczają od Kościoła. To też my, księża polscy pracujący w północnej Francji, nie chcemy tegoukrywać, alezcałkowitym spokojemiodpowiedzialnościąprzedBogiemiprzed waszą Eminencją mówimy i podkreślamy, że główną przyczyną upadku wiary wśród ludu polskiego we Francji, jest nieżyczliwy stosunek księdza francuskiego do księdza polskiego i jego nieumiejętny sposób pasterzowania.

\section{III. Środki zaradcze.}

Księża zastanawiając się nad tym, co wyżej zostało wymienione, doszli do przekonania, że aby złu zaradzić, musi być większa liczba księży polskich i muszą mieć pełną jurysdykcję w stosunku do ludności polskiej. Powinna być większa liczba księży polskich, aby do każdego zakątku mógł dojechać ksiądz polski, aby większe placówki były obsadzone. W dekanacie północnej Francji na 300000 Polaków jest obecnie 13 księży polskich.

Księża polscy powinni być niezależni jurysdykcyjnie od księży francuskich, należałoby nawet utworzyć kościoły oddzielne dla ludności polskiej. Dopóki ksiądz polski bę- 
dzie zależny od księdza francuskiego, zawsze będą nieporozumienia i niesnaski, a ksiądz francuski będzie robił wszystko, aby utrudnić pracę księdzu polskiemu.

Księża polscy maja jeszcze jedną pokorną prośbę do Waszej Ekscelencji. Oto proszą aby Kurie Biskupie wypłacały im ten dodatek pieniężny, jaki otrzymują koledzy w Polsce od Rządu Polskiego. Księża motywują to w ten sposób, że jeśli wyjechali za granicę, jeśli się poniewierają po różnych kątach, jeśli pracują w warunkach nieznośnych, to nie chcieliby być gorzej traktowani, niż księża w Polsce. Zresztą uposażenie, jakie tu otrzymują jest niewystarczające nawet na skromne utrzymanie, to też często żyją w niedostatku. Księża są najmocniej przekonani i ufni, że Wasza Eminencja przychylnie odniesie się do ich prośby.

Księża polscy przedstawiając powyższe sprawy najpokorniej proszą Waszą Eminencję, aby swoimi wpływami uregulował te sprawy, aby okazał się najlepszym Ojcem i Dobrodziejem dla tych setek tysięcy ludności polskiej, która kiedyś była i chce być szczerze katolicką. Niech Ci Polacy w przyszłości nie mówią, że byli przez swoich zaniedbani.

Wszyscy księża zebrani, proszą Waszą Eminencję o błogosławieństwo, przesyłają wyrazy najgłębszej czci i uległości synowskiej.

\author{
X. J. Radwański \\ Dziekan Północnej Francji
}

15 - X - 1928 r. Bruay en Artois (P.de.C.)

\title{
„WE DO NOT WANT TO HIDE IT"-THROUGH THE EYES OF WITNESSES.THE SITU- ATION OF THE POLISH CHAPLAINCY IN NORTH FRANCE IN 1928
}

\begin{abstract}
Summary
The establishing of the „Polish Catholic Mission in France” on 13 May 1922 gave way to the cooperation and agreement aimed at guaranteeing hundreds of thousands of Polish community in this country proper religious care. In France, all the bishops who had a larger number of emigrants in their diocese were supposed to coordinate their efforts to provide those people with pastoral care.

However, as stated by one of the priests, Polish Mission had no legal basis, the reason for its existence was based on a rather problematic agreement between Cardinal Dalbor and Cardinal Dubois, the Archbishop of Paris. Hence, it was not often possible to avoid the tendencies of French Bishops, who were sometimes unfavorably inclined towards national spirit of the Polish emigration. Some French bishops declared their intentions openly in the decree of Bishop Chaptal. Although this circular letter referred to all foreign nations, because of the largest number of Poles in France it was primarily important for the Poles. The presented document exemplifies Polish priests attempting to stop the process of denationalization of their countrymen - silent scream.
\end{abstract}

